\title{
Capillary haemangioma of the testis
}

\author{
P R Mazal, C Kratzik, R Kain, M Susani
}

\begin{abstract}
A case of testicular capillary haemangioma is reported and the importance of intraoperative examination of this very rare lesion emphasised. Capillary haemangioma of the testis can be similar to malignant testicular tumours on clinical presentation, as well as on ultrasonography and magnetic resonance imaging, and therefore should be included in the intraoperative differential diagnosis. Because of the benign nature of this lesion, conservative surgical treatment by means of tumour enucleation with preservation of the testis is possible, if intraoperative examination of frozen sections of representative tissue can be performed. (F Clin Pathol 2000;53:641-642)
\end{abstract}

Keywords: testis; haemangioma

Usually, radical orchidectomy is performed in cases of solid intratesticular tumour. This is the standard procedure, because most testicular tumours in young men are malignant tumours of germ cell origin. We report a case of a capillary haemangioma of the testis, diagnosed on intraoperative examination of the frozen section. Because this is an extremely rare benign testicular tumour, the neoplasm was treated by conservative tumour enucleation with preservation of the testis, instead of orchidectomy.

\section{Case report}

An 18 year old man presented with a palpable, non-tender, left testicular mass approximately $1.5 \mathrm{~cm}$ in diameter. Scrotal sonography revealed a roundish, well demarcated hypoechoic area. Within the lesion echopoor areas were
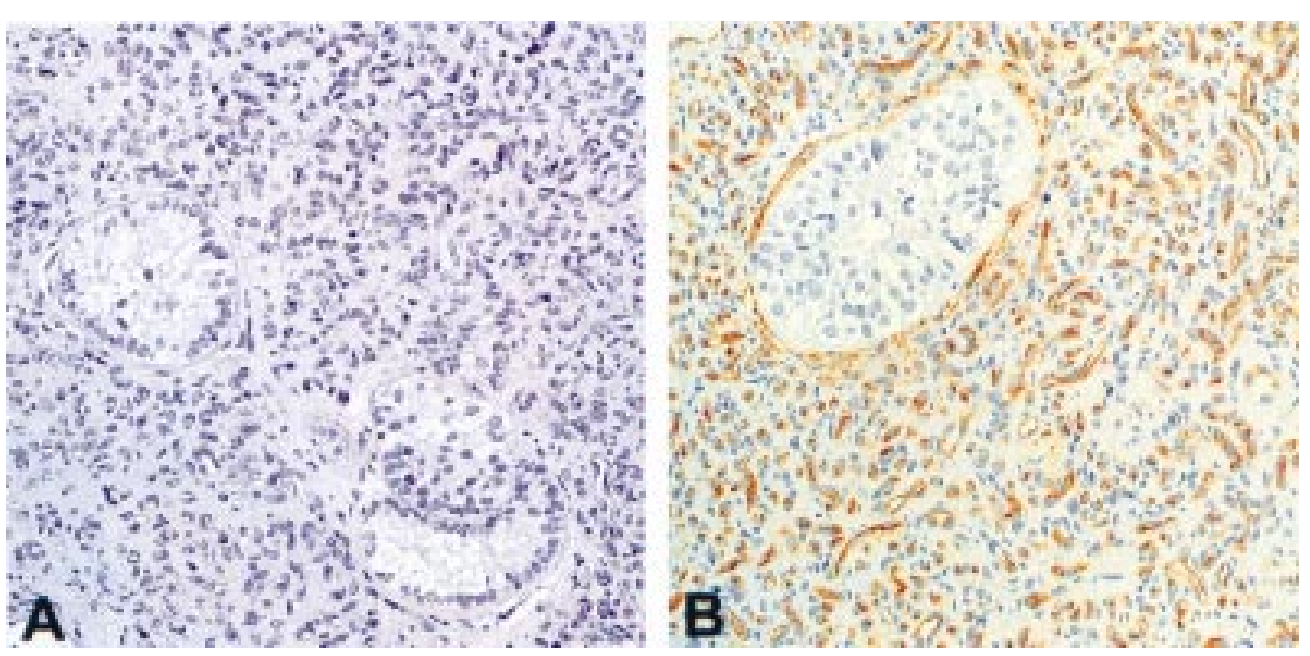

Figure 1 (A) Vascular capillary tumour with abundant vascular spaces, lined by spindle shaped endothelial cells without anaplastic features (haematoxylin and eosin stained; original magnification, $\times 200$ ). (B) Tumour cells showing prominent expression of the vascular marker CD34 (immunohistochemistry for CD34; original magnification, $\times 200$ ).

\section{Discussion}

Testicular capillary haemangioma in adults is an exceptionally rare tumour. In a review of the English literature of the past seven decades we found only four reports of unequivocal capillary haemangiomas of the testis in adults. ${ }^{1-4}$ These patients, similar to our patient, were young men, aged $25,18,45$, and 26 years,

detected. Colour Doppler sonography showed no increased blood flow within the lesion. The tis. Laboratory examinations, including relevant tumour markers, particularly trophin, were normal. Exploration of the left by an inguinal approach revealed a blue/ mass. The excised specimen, nosed as benign angiomatous tumour on intraoxcrative examination of the frozen section. performed, instead of left orchidectomy. traoperative diagnosis of a capillary haemancular tumour with abundant vascular spaces, lined by spindle shaped endothelial cells withwere seen. The tumour tissue was pre-existing tubuli with atrophy were found was well delineated and surrounded by regular seminiferous tubules. Immunohistochemistry and CD34 (fig 1B), as well as vimentin by the tumour cells.
Accepted for publication 29 November 1999
Department of Clinica of Vienna, General

Hospital, Währinger

P R Mazal

R Kain

Department of Urology, University of C Kratzik

Correspondence to: Dr Susa

email: 
Table 1 Vascular tumours of the testis in the literature

\begin{tabular}{lll}
\hline Diagnosis and references & $\begin{array}{l}\text { Number } \\
\text { of cases }\end{array}$ & Age range \\
\hline Capillary haemangioma $^{1-4}$ (present case) & 5 & $18-45$ years \\
Papillary endothelial hyperpalsia $^{5}$ & 1 & 26 years \\
Cavernous haemangioma $^{6-13}$ & 8 & $15-77$ years \\
Histiocytoid haemangioma $^{14-19}$ & 8 & $23-49$ years \\
\hline
\end{tabular}

respectively. Two of the tumours were left sided, ${ }^{12}$ and the other two were right sided. ${ }^{34}$ However, other types of benign testicular vascular tumours in men have also been reported in the literature (table 1). In summary, eight testicular vascular tumours were classified as cavernous haemangiomas. Another eight cases were diagnosed as histiocytoid haemangiomas. ${ }^{20}$ One case was diagnosed as papillary endothelial hyperplasia, ${ }^{5}$ and five cases, including our present case, were classified as capillary haemangiomas.

Whereas cavernous and capillary haemangiomas do not pose major difficulties in diagnosis and classification, the term histiocytoid haemangioma is still a controversial classification. ${ }^{1421}$ It is a unifying concept of vascular neoplasms embracing a clinicopathological spectrum of lesions, proposed by Rosai and co-workers. ${ }^{20}$

A remarkable fact is that no unequivocal de novo malignant vascular testicular tumour has been reported in the English literature. One single published case of a high grade angiosarcoma in the testis was interpreted as secondary sarcomatous transformation of a pre-existing teratomatous germ cell tumour. ${ }^{22}$ To date, all reported vascular testicular tumours have clearly demonstrated benign behaviour, with no evidence of local recurrence or metastasis.

We report another case of testicular capillary haemangioma and emphasise the importance of intraoperative examination of this lesion. Capillary haemangioma of the testis can be similar to malignant testicular tumours on clinical presentation, as well as on ultrasonography and magnetic resonance imaging. ${ }^{4} \mathrm{Be}-$ cause of the benign nature of this lesion, conservative surgical treatment by means of tumour enucleation with preservation of the testis is possible, if intraoperative examination of frozen sections of representative tissue can be performed.

1 Nistal M, Paniagua R, Regadera J, et al. Testicular capillary haemangioma. Br f Urol 1982;54:433.

2 McLennan GT, Quinonez GE, Cooley M. Testicular uvenile capillary hemangioma: conservative management with frozen-section examination. A case report. Can 7 Surg 1994;37:493-4.

3 Nistal M, Garcia-Cardoso JV, Paniagua R. Testicular juvenile capillary hemangioma. F Urol 1996;156:1771.

4 Essig M, Knopp MV, Hawighorst $\mathrm{H}$, et al. MRI of capillary haemangioma of the testis. F Comput Assist Tomogr 1997;21:402-4.

5 Cricco CF, Jr, Buck AS. Hemangioendothelioma of the testis: second reported case. F Urol 1980;123:131-2.

6 Morehead RP, Thomas WC Cavernous hemangioma of testicle. F Urol 1944;51:72-4.

7 Kleiman AH. Hemangioma of the testis. F Urol 1944;51: 548-50.

8 Pfitzenmaier NW, Wurster K, Kjelle-Schweigler M. Haemangioma of the tunica albuginea testis. Urol Int 1975;30: 237-41

9 Fossum BD, Woods JC, Blight EM. Cavernous haemangioma of testis causing acute testicular infarction. Urology 1981;18:277-8

10 Shental J, Fischelovitz J, Sudarsky M, et al. Haemangioma of the tunica albuginea testis. Eur Urol 1982;8:370-1.

11 Gharpure KJ, Ahmed YB, Bhargava MK. Cavernous haemangioma of testis with acute testicular infarction. A case report. Indian f Cancer 1985;22:73-5.

12 Lozano V, Alonso P, Marcos-Robles J. Case report: sonographic appearance of cavernous haemangioma of the sonographic appearance of cavern
testis. Clin Radiol 1994;49:284-5.

13 Frank RG, Lowry P, Ongcapin EH. Venous cavernous haeFrank RG, Lowry P, Ongcapin EH. Venous cavernous
mangioma of the testis. Urology 1998;52:709-710.

14 Banks ER, Mills SE. Histiocytoid (epithelioid) hemangioma of the testis. The so-called vascular variant of adenomatoid tumor. Am f Surg Pathol 1990;14:584-9

15 Stein JJ. Hemangioendothelioma of the testis. F Urol 1975;113:201-3.

16 Davy CL, Tang CK. Are all adenomatoid tumors adenomatoid mesotheliomas? Hum Pathol 1981;12:360-9.

17 Hargreaves HK, Scully RE, Richie JP. Benign hemangioendothelioma of the testis. Am f Clin Pathol 1982;77:637-42.

18 Bell DA, Flotte TI. Factor VIII related antigen in adenomatoid tumors. Implications for histogenesis. Cancer 1982;50: 932-38.

19 Mazzella FM, Sieber SC, Lopez V. Histiocytoid hemangioma of the testis: a case report. $\mathcal{F}$ Urol 1995;153:743-4.

20 Rosai J, Gold J, Landy R. The histiocytoidhaemangioma. A unifying concept embracing several previously described entities of the skin, soft tissue, large vessels, bone, and heart. Hum Pathol 1979;10:707-30.

21 Allen PW, Ramakrishna B, MacCormack LB. The histiocytoid haemangiomas and other controversies. Pathol Annu 1992;2:51.

22 Ulbright TM, Clark SA, Einborn LH. Angiosarcoma associated with germ cell tumors. Hum Pathol 1985;16: $268-72$. 